\title{
TAX EXEMPTIONS FOR HEALTH CARE IN RUSSIA
}

M.E. Orlova

Kazan Federal University, Institute of Management, Economics and Finance, Kazan, Russia

F.F. Adigamova

Kazan Federal University, Institute of Management, Economics and Finance, Kazan, Russia

V.I. Nasyrova

Kazan Federal University, Institute of Management, Economics and Finance,

Kazan, Russia

S.V. Salmina

Kazan Federal University, Institute of Management, Economics and Finance,

Kazan, Russia

E-mail: orlovamarina64@mail.ru

Recepción: 05/08/2019 Aceptación: 20/09/2019 Publicación: 23/10/2019

\section{Gitación sugerida:}

Orlova, M.E., Adigamova, F.F., Nasyrova, V.I. y Salmina, S.V. (2019). Tax exemptions for health care in Russia. 3C TIC. Cuadernos de desarrollo aplicados a las TIC. Edición Especial, Octubre 2019, 346-359. doi: https://doi.org/10.17993/3ctic.2019.83-2.346-359

Suggested citation:

Orlova, M.E., Adigamova, F.F., Nasyrova, V.I. \& Salmina, S.V. (2019). Tax exemptions for health care in Russia. 3C TIC. Cuadernos de desarrollo aplicados a las TIC. Special Issue, October 2019, 346-359. doi: https://doi.org/10.17993/3ctic.2019.83-2.346-359 


\section{ABSTRACT}

In Russia, much attention is paid to the development of the healthcare sector by providing financial direct and indirect support. The granting of tax preferences facilitates the activities of the institutions themselves, since this greatly alleviates the tax burden for them and ensures the inflow of capital and investment in this area. All this contributes to the development of the private medicine sector, increasing the cost of research and development related to health, which in turn brings benefits to the population. The main direction of application of preferences in the field of health care will contribute to the further development of the industry. The extension of the existing preferences, in particular on income taxes, which expires next year, may contribute to the development of both public and private health organizations. Of course, it's not about indefinite exemption from the tax, a developed practice is the establishment of a reduced tax calculation rate, with its subsequent gradual increase. This option is the most lenient for organizations, as a sharp transition from full tax exemption to calculating it at the maximum rate under normal conditions may entail a sharp increase in the tax burden, which can adversely affect the average and small health care businesses just starting its detail.

\section{KEYWORDS}

Taxation of health care facilities, Preferences for healthcare facilities, Value added tax preferences, Reduced social tax rates, Temporary tax preferences. 


\section{INTRODUCTION}

Public health and ensuring for it all the necessary conditions for the provision of health care services is one of the most important tasks of any state. The development of any of the areas, in particular health care, is impossible without government intervention. The need for continuous funding of organizations, investment in research and development requires considerable expenses.

Health care is divided into the public and private sectors, and if state organizations are financed by the state budget, the development of the private sector directly depends on many economic factors, one of which is taxation.

Trends in the change of healthcare institutions in Russia for the period from 2005 to 2016 are presented in Table 1.

Table 1. Dynamics of changes in the number of healthcare institutions in Russia from 2005 to 2016.

\begin{tabular}{|c|c|c|c|c|c|c|}
\cline { 2 - 7 } & 2005 & 2010 & 2013 & 2014 & 2015 & 2016 \\
\hline $\begin{array}{c}\text { The number of registered } \\
\text { medical organizations in } \\
\text { health care. }\end{array}$ & 36117 & 26174 & 25981 & 26987 & 27525 & 26556 \\
\hline $\begin{array}{c}\text { Of them: } \\
\text { Nongovernmental }\end{array}$ & 2934 & 2240 & 2338 & 2465 & 2459 & 2660 \\
\hline State & 33183 & 23219 & 23100 & 24056 & 24286 & 23091 \\
\hline
\end{tabular}

Source: (Russia in numbers, 2017).

Under the conditions of reforming the health care system for the period, the total number of health care institutions for the study period decreased by $26.4 \%$. Reduction occurred only in a group of government organizations.

Russia has three channels for financing health care institutions: budgetary, state medical insurance and extrabudgetary.

The health of certain groups of the population and the overall effectiveness of health care depend heavily on the method of financing the health system. The state provides the health care system with the necessary financial resources to provide the population with high-quality, affordable, timely medical care. On average, total government spending on health care amounts to $3.5 \%$ of GDP. 
Unfortunately, there is a decrease in this indicator. Unfortunately, there is a decrease in this indicator. Since the beginning of the reform of the health care system, budget expenditures for these purposes have been reduced by almost 100 billion rubles (from 401.1 billion in 2014 to 302.4 billion rubles in 2016) (Akishkin, 2014).

\section{METHODOLOGY}

In conducting the study, the methods of comparison and generalization, methods of statistical analysis and methods of analogy for determining risks were used.

\section{RESULTS AND DISCUSSION}

The nomenclature of health facilities was approved by the Ministry of Health of the Russian Federation on August 06, 2013. N. ${ }^{\circ}$ 529n. According to this nomenclature by type of activity medical organizations are divided into three large groups: treatment-and-prophylactic, organizations of a special type, organizations for supervision in the field of consumer protection. Each group has its own details, including from five to more than thirty institutions, each of which may specialize in a specific topic.

The preferential terms of application prescribed in the Tax Code of the Russian Federation, incl. tax rates, do not allocate with this separately taken types of institutions, and mainly apply to one or another type of there activity.

Health care institutions in Russia can use the general tax regime and the special tax regime in the form of a simplified tax system (Table 2). These are taxes for which no preference is provided.

Table 2. Dynamics of taxes paid by health care institutions, billion rubles.

\begin{tabular}{|c|c|c|c|c|c|c|c|c|}
\hline Year & $\begin{array}{c}\text { Income } \\
\operatorname{tax}\end{array}$ & $\begin{array}{l}\text { Personal } \\
\text { income } \\
\text { tax }\end{array}$ & VAT & $\begin{array}{l}\text { Excise } \\
\text { taxes }\end{array}$ & $\begin{array}{l}\text { Taxes on } \\
\text { the use } \\
\text { of natural } \\
\text { resources }\end{array}$ & $\begin{array}{l}\text { Property } \\
\text { tax }\end{array}$ & $\begin{array}{l}\text { Special tax } \\
\text { regime }\end{array}$ & $\begin{array}{c}\text { Social } \\
\text { contributions }\end{array}$ \\
\hline 2015 & 5,4 & 191,0 & 8,50 & 0 & 0,03 & 9,95 & 5,60 & no data \\
\hline 2016 & 5,4 & 191,0 & 8,50 & 0,01 & 0,03 & 9,95 & 5,60 & no data \\
\hline
\end{tabular}




\begin{tabular}{|c|c|c|c|c|c|c|c|c|}
\hline Year & $\begin{array}{c}\text { Income } \\
\operatorname{tax}\end{array}$ & $\begin{array}{l}\text { Personal } \\
\text { income } \\
\text { tax }\end{array}$ & VAT & $\begin{array}{l}\text { Excise } \\
\text { taxes }\end{array}$ & $\begin{array}{l}\text { Taxes on } \\
\text { the use } \\
\text { of natural } \\
\text { resources }\end{array}$ & $\begin{array}{l}\text { Property } \\
\text { tax }\end{array}$ & $\begin{array}{l}\text { Special tax } \\
\text { regime }\end{array}$ & $\begin{array}{c}\text { Social } \\
\text { contributions }\end{array}$ \\
\hline 2017 & 4,5 & 5, 209 & 8,10 & 0,00 & 0,03 & 7,70 & 7,00 & 435,00 \\
\hline 2018 & 5,0 & 256,8 & 8,90 & 0,00 & 0,03 & 7,90 & 8,70 & 532,80 \\
\hline $\begin{array}{c}2018, \\
\%\end{array}$ & 0,7 & 30,5 & 1,1 & 0 & 0 & 3,5 & 1,1 & 63,2 \\
\hline
\end{tabular}

Source: (Ponyuhov, 2016).

If state organizations are financed by the state budget, the development of the private sector directly depends on many economic factors, one of which is taxation Health care is an industry in which the main burden falls on the wage fund, more than $60 \%$.

The main preferences provided for health organizations relate to VAT and income tax. In certain regions of the Russian Federation privileges on property tax may be established.

Table 3. Tax preferences for health organizations.

\begin{tabular}{|c|c|c|}
\hline TAX & $\begin{array}{c}\text { Types of medical and health } \\
\text { organizations }\end{array}$ & Preferences \\
\hline $\begin{array}{l}\text { Income } \\
\operatorname{tax}\end{array}$ & $\begin{array}{l}\text { State, municipal } \\
\text { and private medical } \\
\text { and health organizations }\end{array}$ & $\begin{array}{c}\text { Art. } 251 \text { of the Tax Code of the Russian Federation - non- } \\
\text { taxable income } \\
\text { Art. } 284.1 \text { of the Tax Code of the Russian Federation - } \\
\text { application of the Oth rate }\end{array}$ \\
\hline VAT & $\begin{array}{l}\text { State, municipal } \\
\text { and private medical } \\
\text { and health organizations }\end{array}$ & $\begin{array}{l}\text { Art. } 145 \text { of the Tax Code of the Russian Federation - full } \\
\text { exemption from VAT } \\
\begin{array}{c}\text { Art. } 149 \text { of the Tax Code of the Russian Federation - (paragraph } \\
2 \text { of paragraphs 1,2) exemption from taxation of certain } \\
\text { operations. }\end{array} \\
\begin{array}{c}\text { Art. } 164 \text { of the Tax Code of the Russian Federation (clause 2, } \\
\text { clause } 4 \text { ) -application of a reduced rate of } 10 \% \text { on VAT }\end{array}\end{array}$ \\
\hline $\begin{array}{l}\text { Property } \\
\text { tax }\end{array}$ & $\begin{array}{l}\text { State, municipal } \\
\text { and private medical } \\
\text { and health organizations }\end{array}$ & Tax legislation of the subjects of Russia \\
\hline Land tax & $\begin{array}{l}\text { State, municipal } \\
\text { and private medical } \\
\text { and health organizations }\end{array}$ & Decisions of municipal representative bodies \\
\hline $\begin{array}{l}\text { Transport } \\
\operatorname{tax}\end{array}$ & $\begin{array}{l}\text { State, municipal } \\
\text { and private medical } \\
\text { and health organizations }\end{array}$ & Tax legislation of the subjects of Russia \\
\hline
\end{tabular}

Source: Tax Code of Russia (Tax Code (Part I) of the Russian Federation of July 31, 1998; Tax Code (Part II) of August 5, 2000). 
A change in the established tax rates for individual taxes and taxpayers, whether on an urgent or a perpetual basis, can either increase interest in a particular area or restrain its development, if necessary. Since the subject of our research is healthcare institutions and their activities, let us consider what kind of "relief" the legislator provides for this category of taxpayers.

One cannot but agree with the opinion of the researchers that the development of tax preferences is necessary not only for the health care organizations themselves, but also for private investors in this field (Dadashev, Meshkova, \& Topchi, 2016). For Russia, at present, the use of aggressive tax optimization methods is questionable. Moreover, the institution receives an additional competitive advantage as a bona fide taxpayer (Retz, 2015). When applying the tax preferences of a health care institution, in order to minimize the risks of violating tax laws and holding them accountable, they must maintain internal tax control over the implementation of the established framework for the use of benefits (Ponyuhov, 2016).

The preferences for the value added tax in the field of health care are associated with the exemption from taxation of certain operations and the implementation of the conditions for their use established in paragraph 2 of Article 149 of the Tax Code of Russia. Growth of falling incomes of the budget on the VAT in the field of public health services is observed. At the same time, the number of declarations in which this preference is declared is decreasing.. (Picture 1).

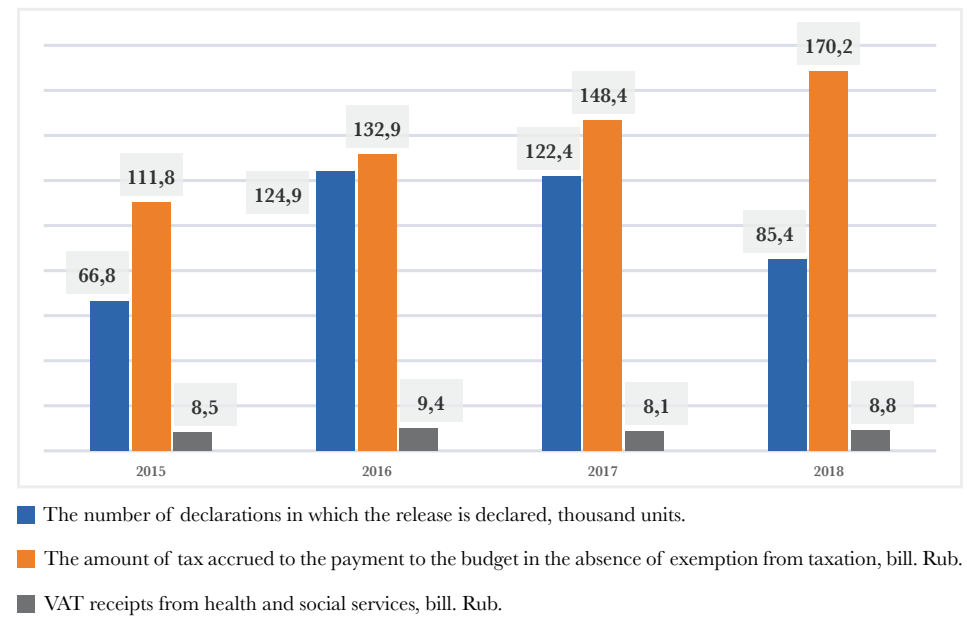

Picture 1. Dynamics of shortfall in income on VAT on health care institutions and tax returns. Source: (Ponyuhov, 2016). 
According to a number of specialists in the field of organization and economics of health care, the current exemption of medical services from VAT is essentially no incentive for the development of entrepreneurship in health care and, at the same time, does not have any impact on the financial situation of medical organizations. According to experts, with the help of these tax benefits, the state is trying to limit the prices of paid medical services. And this is beneficial, first, to consumers, that is, patients, which, of course, cannot be regarded as an exclusively positive point in the practice of taxation (Podogova \& Orlova, 2018).

Tax preferences for VAT exceed the actually received VAT from the health care industry by 19 times. Russian health care institutions are actively using the right to association. Based on the statistical reporting data of the Federal Tax Service of Russia, the dynamics of tax expenditures, when applying VAT exemptions for medical goods and services, health services are presented in the Picture 2.

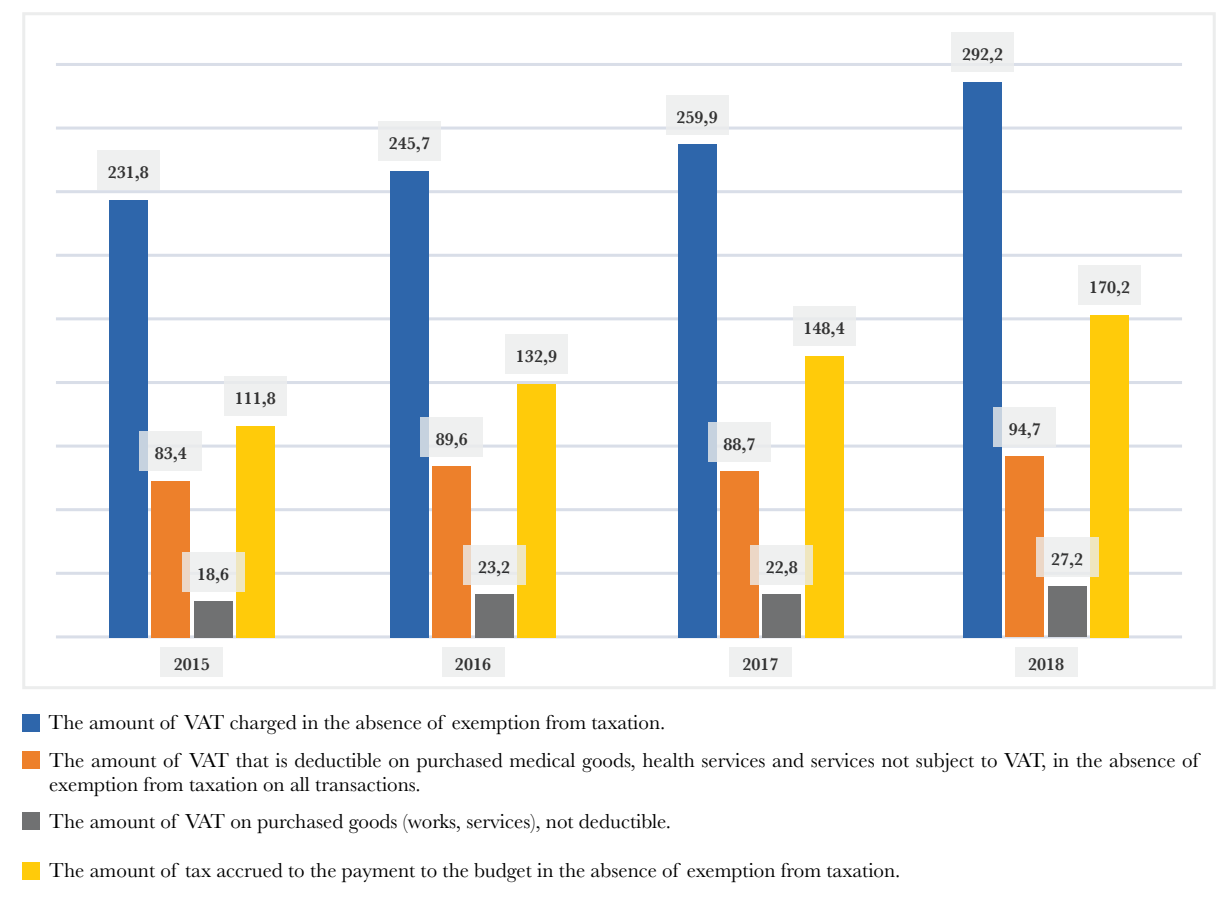

Picture 2. The dynamics of falling budget revenues in connection with the application of exemptions by health care institutions under paragraph 2 of Art. 149 TC RF, bill. Rub. Source: (Ponyuhov, 2016). 
Preferences are offered for health care facilities and for income tax. According to clause 1.1 of Article 284 of the Tax Code of the Russian Federation, organizations engaged in medical activities have the right to apply a tax rate of $0 \%$ on income tax for the period from January 1, 2011 to January 1, 2020. Established the need to comply with certain conditions: the availability of a license, the compliance of the services provided to the established list of operations and separate accounting (Tax Code (Part II) of August 5, 2000). The possibility of applying the $0 \%$ tax rate is provided when performing the following procedures: notifying the tax authority of this preference application, license availability, compliance of the services provided to the established list of operations, income from medical activities more than $90 \%$, at least 15 employees, $50 \%$ and more work continuously in the state certified specialist (Tax Code (Part II) of August 5, 2000).

Until 2019, social tax preferences were established. For example, organizations engaged in the production of medicines, medical instruments and equipment, carrying out activities in the field of health care, as well as pharmacies, single tax payers with no imputed income, had the right to apply a lower insurance premium rate for the period 2017-2018. This preference exempted them from paying contributions to compulsory medical and social insurance funds and reduced the rate for contributions to the pension insurance fund from $22 \%$ to $20 \%$.

\section{SUMMARY}

The provision of preferences for one of the most important taxes, the rates for which are quite high (value added tax - 20\% from 2019, corporate income tax - $20 \%$, insurance premiums at the basic rate - $30 \%$ of wages), provides milder operating conditions and has a positive impact on the health sector, ensuring growth in investment, capital inflows and a growing number of non-governmental institutions. 
Table 4. The number of health organizations in the period 2014-2016.

\begin{tabular}{|c|c|c|c|}
\hline Year & $\begin{array}{c}\text { Total } \\
\text { number of health } \\
\text { organizations, th. }\end{array}$ & $\begin{array}{c}\text { Number of private health } \\
\text { organizations, th. }\end{array}$ & $\begin{array}{c}\text { The share of private health } \\
\text { organizations in the total, } \%\end{array}$ \\
\hline 2014 & 83,2 & 51,4 & 61,7 \\
\hline 2015 & 86,0 & 55,1 & 64,0 \\
\hline 2016 & 85,9 & 56,5 & 65,8 \\
\hline
\end{tabular}

Source: (Russia in numbers, 2018).

During the period under review, the number of nongovernmental organizations in the health sector increased by $10 \%$. The trend of growth of this indicator is observed at the present time, despite the fact that the total number of health care organizations is declining: in 2017 their number decreased compared to 2016 by $6.6 \%$ and amounted to 80.3 thousand.

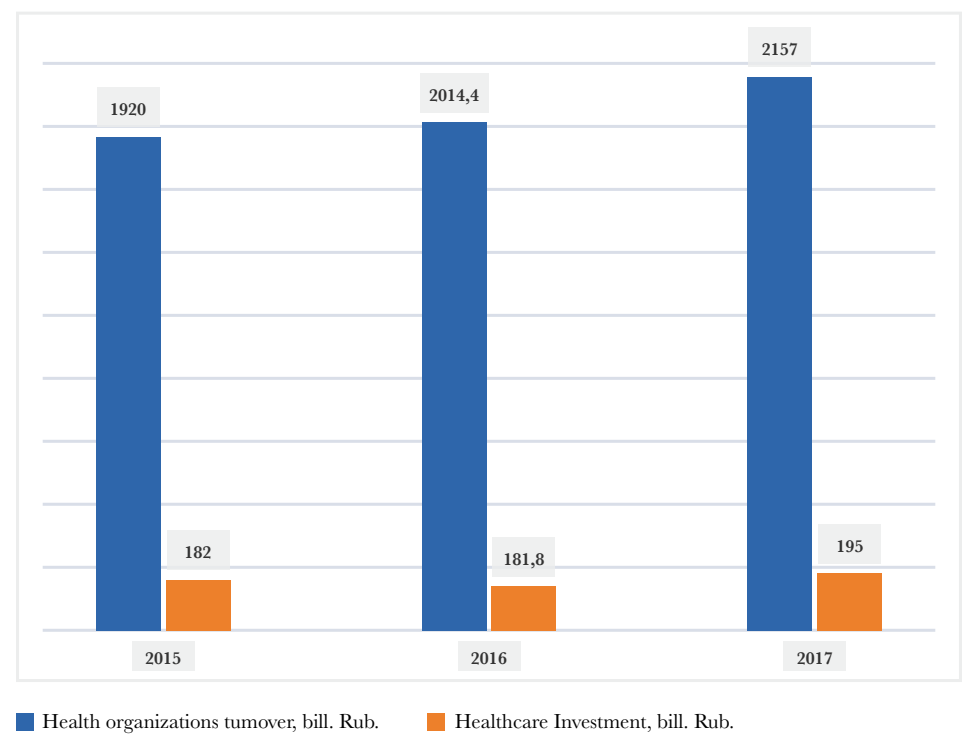

Picture 3. Service revenue of organizations and investments in fixed assets in the field of health. Source: (Russia in numbers, 2018; Russia in numbers, 2017).

There is a tendency of growth at once on two indicators: turnover of organizations and investments made in fixed assets. In the period from 2015 on 2017 turnover of health organizations increased by $12 \%$, and investment in fixed assets in the field by $7 \%$. At the same time, given that the overall growth rate of investment in 
all areas in 2017. in relation to the indicators of 2016 . increased by only $4.2 \%$; an increase in investment separately in the healthcare sector by $7 \%$ is a good indicator.

Another confirmation of the active development of the health sector in recent years is also the fact that the cost of research and development in the direction of "protecting the health of the population" over the past 10 years has doubled, reaching in 2017. 30.5 billion rubles (Russian statistical yearbook, 2018, c.485). Comparing the figures we cited, especially the amount of investments and turnover of organizations for the period 2015-2017, we can say that the provision of tax preferences in the health sector gives a positive result.

Providing this kind of preferences for exemption from tax payment or the use of a reduced rate when calculating it is, undoubtedly, a kind of support for organizations, but for the state this means under-received funds to the budget. That is why most of the preferences listed by us are temporary: the application of the reduced tariff on insurance premiums has not been implemented since 2019, the application of the $0 \%$ rate on income tax is limited to 2020 .

The abolition of the preferences provided is natural, since initially their introduction provides for a temporary nature. However, the health care sector is not the sector that can have priority in development today, but tomorrow it will give way to the production or services sector. As mentioned earlier, the health sector is always one of the most important for its maintenance and development.

\section{CONCLUSIONS}

Based on illustrative examples, based on official statistics, we can assume that the extension of the existing preferences, in particular on income taxes, which expires next year, may contribute to the development of both public and private health organizations. Of course, we are not talking about indefinite exemption from the tax, a developed practice is the establishment of a reduced tax calculation rate, with its subsequent gradual increase. This option is the most lenient for 
organizations, as a sharp transition from full tax exemption to calculating it at the maximum rate under normal conditions may entail a sharp increase in the tax burden, which can adversely affect the average and small health care businesses just starting its detail.

As a result of the study, the following problems were identified:

- Lack of reporting on the assessment of the effectiveness of tax preferences for health care organizations;

- Tax preferences for organizations carrying out scientific research in the field of medicine and health care are not enough.

In order to solve the first problem, we recommend using the criteria for evaluating the efficiency of tax benefits of health care institutions: an increase in the cost of equipment (technical base) of a medical organization, an increase in the indicators of high-tech medical care, an increase in the indicators of medical care in nosology and introduce appropriate reporting from health organizations.

To solve the problems of the second group, it is advisable to introduce tax holidays for VAT and income tax for companies implementing new medical equipment, VAT and income tax for companies that are developing new drugs, property tax for healthcare organizations carrying out introduction of new development of equipment for medicine.

\section{ACKNOWLEDGEMENT}

The work is performed according to the Russian Government Program of Competitive Growth of Kazan Federal University. 


\section{REFERENCES}

Akishkin, V. G. (2014). Regional Health Care in the Context of Institutional Transformations: The Economic and Financial Aspect: Monograph. Volgograd: Volgograd scientific ed.

Dadashev, A. Z., Meshkova, D. A., \& Topchi, Y. A. (2016). Development of the financial mechanism and taxation of social organizations. Finance and Credit, 2-14.

Podogova, D., \& Orlova, M. (2018). Improving the conditions of taxation of medical and health organizations in Russia. International science project, 19, 49.

Ponyuhov, E. V. (2016). Internal Control as a Factor in Reducing Tax Risks in Healthcare Institutions. Saint-Petersburg State Economic University.

Retz, V. V. (2015). Ways to Optimize the Taxation of Autonomous Institutions. News of the Russian Economic University.

Russia in numbers. (2017). Federal State Statistics Service. Retrieved from http:// www.gks.ru/free_doc/doc_2017/rusfig/rus17.pdf

Russia in numbers. (2018). Federal State Statistics Service. Retrieved from http:// www.gks.ru/free_doc/doc_2018/rusfig/rus18.pdf/

Russian statistical yearbook. (2018). Federal State Statistics Service. Retrieved from http://www.gks.ru/free_doc/doc_2018/year/year18.pdf/

Statistics and Analytics of the Federal Tax Service of Russia. Retrieved from https: / / www. nalog.ru/rn16/related_activities/statistics_and_analytics/forms/6911382/

Tax Code (Part I) of the Russian Federation. (July 31, 1998). N. ${ }^{\circ} 146$ - FZ. Collected Legislation of the Russian Federation. N. ${ }^{\circ}$ 31, art. 3824.

Tax Code (Part II) of the Russian Federation. (August 5, 2000). N. ${ }^{\circ} 117$ - FZ. Collected Legislation of the Russian Federation. N. ${ }^{\circ}$ 32, art. 3340. 
Edición Especial Special Issue Octubre 2019 DOI: https://doi.org/10.17993/3ctic.2019.83-2.346-359 